\title{
Analysis of Reward and Punishment Programs towards Job Satisfaction of Sales Promotion Girl (SPG) at Matahari Metropolitan Mall Department Store Bekasi
}

\author{
Bintang Narpati ${ }^{1}$ \\ \{b.narpati@gmail.com ${ }^{1}$ \} \\ ${ }^{1}$ Faculty of Economic, Universitas Bhayangkara Jakarta Raya, Jl. Raya Perjuangan No.81, Marga \\ Mulya, Bekasi Utara, Kota Bekasi, Jawa Barat 17143, Indonesia.
}

\begin{abstract}
This study aimed to measure the effect of reward and punishment programs that have been applied in working on job satisfaction of Sales Promotion Girl (SPG) at Matahari Department Store Metropolitan Mall Bekasi. The method used in this study, using quantitative descriptive analysis with involving 120 (one hundred and twenty) Sales Promotion Girls (SPG) and using random sampling techniques. The method of collecting data through a questionnaire and interview method which supported by the documentation method. Linear regression analysis is a technique used in analyzing this data. Based on the results of this study it can be obtained that there are significant influence between reward programs towards job satisfaction, there is a significant influence between program punishment towards employee job satisfaction and there are significant influence between reward and punishment program towards job satisfaction simultaneously. Through this research can be concluded that the existence of reward and punishment program can affect the job satisfaction of Sales Promotion Girl (SPG) at Matahari Department Store Metropolitan Mall Bekasi
\end{abstract}

Keywords: Reward, punishment, job satisfaction.

\section{Introduction}

Job satisfaction is a feeling that wants to be felt by employees who work in an agency or other institution so that they can carry out their work every day with enthusiasm. In creating job satisfaction can not be separated from the policies - policies implemented by the company to all employees so that employees can comply with regulations that have been made and are binding. Growing the enthusiasm of employees in work is certainly not something easy, because many companies are finally demoed by their employees because there is a feeling of dissatisfaction in working for their employees.

Reward and punishment is a balance of life in work. On the one hand the company will provide rewards for employees who achieve targets and comply with company regulations while on the other hand employees will get punishment if employees do not comply with company regulations and do not reach the targets set by the company.

The forms of reward and punishment for each company are different, but there are also many who apply almost the same as other companies. Reward and punishment is indicator of job satisfaction. 
PT. Matahari Department Store Metropolitan Mall Bekasi, is the largest outlet in the field of fashion and employs many employees, namely Sales Promotion Girl (SPG) in serving its customers. At Matahari Department Store Metropolitan Mall Bekasi, employee turnover that occurs is quite high. One of the indicators is reward and punishment that can affect employee job satisfaction.

\section{Reward, Punishment and Job Satisfaction}

Reward is a stimulus for employees given by the company to achieve the set targets. Each company determines the level of graduation or achievement of targets in each division or to individuals or employees, with the aim of both individually and in groups to be motivated. Rewards given by companies to their employees can vary between organizations. But basically the reward is given because employees have achievements that can improve company performance. Reward given to employees include the amount and weight [1]. The company provides rewards to employees based on how much employees contribute in providing skills, thoughts and energy in developing performance to the company. If the employee has a large contribution and has a positive value on the development of the company, the company will provide rewards that are in accordance with the contributions given to its employees. Reward is given by the company to employees in several ways including increasing performance, large contributions in the company, competencies or skills possessed in carrying out operational tasks or in service, in addition the company provides retirement benefits as rewards to outstanding employees [2].

There are three components of an effective reward program for employees, namely direct, short and long term rewards. Achievements for good performance can be given direct rewards, while for the short term can be given every month or every three months, and for the long term, rewards can be given every year as a form of employee loyalty to the company [3]. By providing motivation in the form of rewards to employees will create job satisfaction and employees have a high commitment to the organization in addition to maximum service will also be provided by employees both to the company and to customers. For this reason, management should create a reward program that is in accordance with the circumstances of the organization [4].

In addition, rewards can retain employees who are resigned or fired by motivating employees through open communication, creating award programs for outstanding employees, career development programs for each employee, giving bonuses based on employee performance, recreational facilities for corporate and family environment and giving gifts to certain events [5].

Punishment is a form of consequence for an employee who cannot adjust to the expectations of the company whether it is the achievement of targets, company regulations or other norms. With the existence of punishment, it is expected that all employees can be motivated to fulfill the wishes of the company. Employees get punishment because their actions or morals are not in accordance with the regulations set by the company. This punishment helps to reduce violations committed by employees in the future [6]. Before giving a punishment, the leader of the company should know the background of the problem of employees who violate the company. First, look at how often the employee does a violation. These violations can be seen from the accuracy of the time of arrival to the office, the level of attendance, often leaving work during rush hour and other norm violations.

Technology development is needed in giving penalties to employees who violate company regulations. With changes in technology that are systematically designed will have 
an effective impact on changes in employee behavior [7]. Like employees who often arrive late will be monitored by several leaders of the organization and other employees. Then it will be inputted by the computer system automatically. With changes in technology in the field of attendance, it is hoped that this can cause a deterrent effect for employees who often come late. Through the punishment regulations applied by the company, employees will be better off avoiding punishment than getting the reward offered by the company [8]. Punishment that has been made by company management is binding for all employees from the lower level to the top level and the criteria for employees who get punishment have been stated in the rules that have been made by the management of the company. Job satisfaction is a pleasant feeling experienced by an employee that can be realized by increasing motivation in work. However, job satisfaction for each employee is different due to other factors that influence it. Job satisfaction is an emotional feeling for employees of the work they do. Every employee has different job satisfaction. The level of job satisfaction for individuals can be measured by increasing their performance by making a few mistakes and contributing a lot to the company.

Increased job satisfaction will have an impact on increased work performance and organizational commitment [9]. Job satisfaction that is owned by employees is related to several variables including turnover, attendance rate, age, level of work received and the size of company organization. Job satisfaction that is owned by each employee is different because it depends on several factors including salary received, promotion, employment, supervision carried out by superiors, working conditions that support and team work.

In a company having job satisfaction for each employee is something that can be equalized or different. These factors include The salary received is appropriate or not because the employee compares the work with the reward received, A conducive work environment that provides a sense of comfort in work, Solid team work that helps each other to achieve targets set by the company, Jobs that are in accordance with the competencies of the employees involved, The role of a wise leader by giving motivation and attention to his subordinates.

Job satisfaction for employees can be categorized by providing financial and psychological rewards. Financial rewards in the form of physical forms are usually in the form of money, goods and the like while psychological rewards are related to the recognition of the company to employee performance [10].

\section{Method}

The method in the research used is quantitative descriptive analysis. The research location is Matahari Department Store Metropolitan Mall Bekasi. Population and sample are Sales Promotion Girl employees. The method of data collection was carried out with a questionnaire distributed and conducted interviews with the leadership of the Matahari Department Store Metropolitan Mall Bekasi. This method uses a random sampling technique with 120 employees. Reward and punishment given by the company to its employees is a common thing for companies.

There are several companies that implement this reward and punishment program, almost the same as other companies, but some are different from the others. In improving company performance, almost all companies implement this reward and punishment program, but in practice this program is not necessarily acceptable to all employees who work. There are some employees who are not comfortable with this program so they have to leave the company because the program is implemented. 


\section{Analysis of Reward and Punishment Program towards Job Satisfaction of Sales Promotion Girl at Matahari Department Store Metropolitan Mall Bekasi}

The company's goal is to achieve the vision and mission that it has set with the support of its employees, stakeholders and shareholders. In achieving these objectives, companies implement various kinds of reward and punishment so that employees have satisfaction in working and can improve their performance. This Reward Program and Education is a supporting tool for company regulations that have been made. In addition to increasing job satisfaction and motivation, this reward and punishment program is an assessment of employee performance carried out by company management.

The Reward and Punishment Program is the opposite of the policies implemented by the company. On the one hand, reward is a form of appreciation for the achievement of employees on targets set by the organization. According to some previous opinions that reward is an effort from someone to foster feelings to be accepted and recognized in the work environment, by getting in the form of compensation and relationships with other employees, but on the other hand punishment is a form of punishment that must be accepted by an employee because he does not achieve the target or violating the rules of the company as the previous opinion that punishment is manifested in the form of threats with the aim of improving the performance of employees who violate, in order to comply with applicable regulations in the company and provide lessons to employees who violate.

Both of these programs are basically forms of motivation desired by the company so that every employee carries out the goals set by the company but in reality the form of reward and punishment can also be demotivating for the company. Like rewards received by employees are not in accordance with expectations and punishment that is considered too heavy for employees can make employees unmotivated at work and resignation. One indicator of the achievement of job satisfaction for an employee Sales Promotion Girl (SPG) is the achievement of targets set by the company and employees comply with the applicable regulations in the company and each year the average performance increases this can be indicated by the performance assessment carried out on the employee.

\section{Hypothesis}

Reward and punishment programs can affect job satisfaction of employees and depend on how employees respond, some like this program and some do not, so it can be said that this reward and punishment program can affect employee job satisfaction.

In figure 1, explains the hypothesis with formulation:

H1 : Is there a significant influence between the Reward program on Job Satisfaction?

$\mathrm{H} 2$ : Is there a significant influence between the Punishment program on Job Satisfaction?

H3 : Are there significant influence between the Reward and Punishment Program on Job Satisfaction simultaneously? 


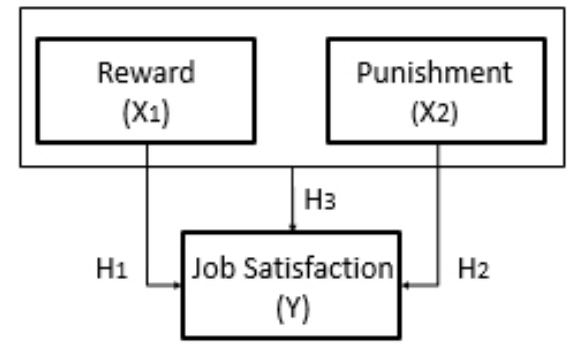

Fig.1. Relationship between Reward and Punishment on Job Satisfaction

Data analysis techniques are done by collecting data by distributing questionnaires and supported by documentation methods. The analysis technique or method used is a multiple linear regression analysis technique. This data analysis method using SPSS (Statistical Package for Social Science) for Windows version 24.0 obtained data quality test results for validity testing of 2 independent variables namely reward and punishment and Job satisfaction dependent variable obtained by $r$-count $>$ r-tabel which is above the value of 0,1793 so the questionnaire is said to be valid, while the Reliability Test shows that the independent and bound variables have Cronbach Alpha values> r-table $(0,60)$, namely Reward $\left(\mathrm{X}_{1}\right)$ of 0,707 , Punishment $\left(\mathrm{X}_{2}\right)$ of 0,606 and Job Satisfaction $(\mathrm{Y})$ of 0,730 so that the variables both free and bound are said to be reliable. Requirements test in this analysis can be continued in testing hypotheses, namely:

\subsection{Normality Test}

Looking at the normal probability plot, it can be seen that the distribution pattern is close to normal because the points follow a straight line in a diagonal direction so that the regression model is feasible in the assumption of normality.

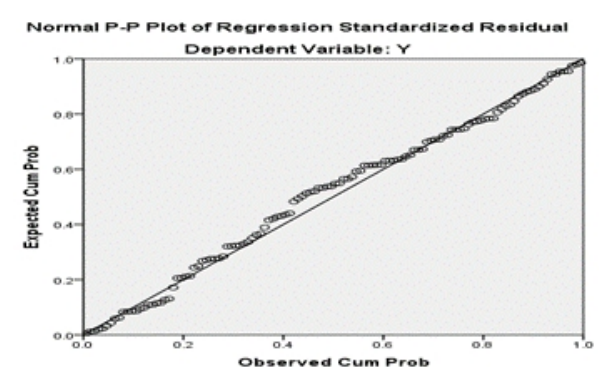

Fig.2. Normality Test

\subsection{Multicollinearity Test}

Multicollinearity test is a test to determine whether there is a significant correlation between independent variables in multiple linear regression models. Tolerance value of $0,410>0,10$ and VIF value of $2,439<10$. Based on the results of the multicollinearity test, no multicollinearity was found.

\subsection{Heteroscedasticity test}


The Heteroscedacity test is used for the presence of variance and residual inequalities for all observations in the regression model. The results of the Heteroscedasticity test show that the data points spread above and below or around the number 0 and not form a pattern.

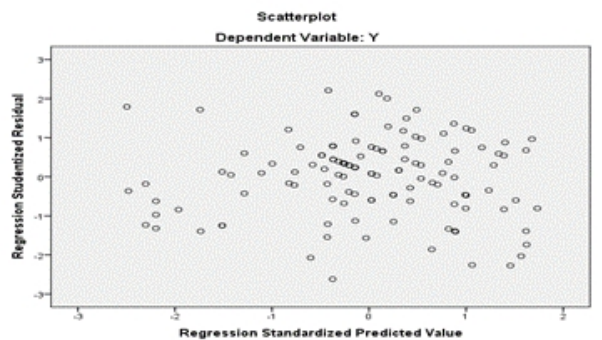

Fig.3. Heteroscedasticity Test

\subsection{Autocorrelation Test}

This method uses Durbin Watson (DW). The DW value is 2,020 so $1,7361<2,020$ $<2,5639$, there is no autocorrelation.

\section{Multiple Linear Analysis} where:

The regression equation can be formulated as follows: $\mathrm{Y}=11,567+0,462 \mathrm{X}_{1}+0,149 \mathrm{X}_{2}$,

$$
\begin{array}{ll}
\mathrm{Y} & =\text { Job Satisfaction, } \\
11,567 & =\text { Constant } \\
0,462 \text { and } 0,149 & =\text { Regression Coefficient } \\
\mathrm{X}_{1} & =\text { Reward } \\
\mathrm{X}_{2} & =\text { Punishment }
\end{array}
$$

\section{Description of Research Result Analysis}

The research entitled "Analysis of Reward and Punishment Programs to Job Satisfaction Sales Promotion Girl (SPG) at Matahari Department Store Metropolitan Mall Bekasi" uses two independent variables and one dependent variable. The two independent variables are Reward and Punishment. One dependent variable is Job Satisfaction. In order to reveal the existing data and to prove the hypothesis that has been stated, then in collecting data using a questionnaire. Based on the data from the questionnaire results to the respondents it can be seen the following results:

In the coefficient table the regression equation is obtained, $\mathrm{Y}=11,567+0,462 \mathrm{X}_{1}+$ $0,149 \mathrm{X}_{2}$. The constant of 11,567 states that if there is no influence between reward or punishment programs, the amount of job satisfaction is 11,567. Regression coefficient $\mathrm{X}_{1}=$ 0,462 states that every increase in reward program will increase job satisfaction by 0,3462 . Regression coefficient $\mathrm{X}_{2}=0,149$ states that every increase in punishment will increase job satisfaction by 0.149 . Based on the calculation results in the summary model, the R Square number is 0,457 . This means that $45,7 \%$ job satisfaction can be explained by these two variables. While the remaining $54,3 \%$ or $(100 \%-45,7 \%)$ are other variables that were not present in this study, such as motivation, leadership, work environment, work culture and others. 


\subsection{The Reward Effect toward Job Satisfaction}

Based on the results of calculations using the $t$ test, the value of the variable use of reward $\left(\mathrm{X}_{1}\right)$ is obtained at 7,030 with sig. level of 0,05 and $t$-table of 1,980 . Because the value of $t-$ count $>\mathrm{t}$-table $(7,030>1,980)$ then $\mathrm{H}_{0}$ is rejected, meaning that partially there is a significant positive effect between the use of reward on Job satisfaction.

\subsection{The Effect of Punishment toward Job Satisfaction}

Based on the results of calculations using the $t$ test, the $t$-count value of the punishment use variable $\left(\mathrm{X}_{2}\right)$ is 2,446 with a significance level of 0,05 and t-table of 1,980 . Because the value of $\mathrm{t}$-count $>\mathrm{t}$-table $(2,446>1,980)$ then $\mathrm{H}_{0}$ is rejected, meaning that partially there is a significant positive effect between the use of punishment on Job satisfaction.

\subsection{The Effects of Reward and Punishment toward Job Satisfaction}

Based on the results of calculations using the F test, obtained F-count value of 49,170 with a significance level of 0,05 and F-table of 3,100. Because the value of F-count $>$ F-table $(49,170>3,073)$ then $\mathrm{H}_{0}$ is rejected, meaning that there is a significant influence between the use of reward and the use of punishment on Job satisfaction.

\subsection{Effective Contributions}

Effective contributions of $\mathrm{X}_{1}$ and $\mathrm{X}_{2}$ predictor variables to criterium, namely $\mathrm{X}_{1}$ is more dominant to $\mathrm{Y}$ with a value of $36,42 \%$, while $\mathrm{X}_{2}$ has a value of $9,25 \%$ to $\mathrm{Y}$.

\subsection{Relative Contribution}

Relative contribution of $\mathrm{X}_{1}$ and $\mathrm{X}_{2}$ predictor are variables to criterium, namely $\mathrm{X}_{1}$ is greater than $Y$ with a value of $79,75 \%$, while $X_{2}$ has a value of $20,26 \%$ against $Y$.

The magnitude of the contribution / influence of the two independent variables namely reward $\left(\mathrm{X}_{1}\right)$ and Punishment $\left(\mathrm{X}_{2}\right)$ observed on the dependent variable Job satisfaction $(\mathrm{Y})$ expressed by the value of $R$ Square or the determination coefficient $R$ Square $\left(R^{2}\right)$ obtained a value of 0,457 . This value means that the contribution / influence of the two independent variables namely reward $\left(\mathrm{X}_{1}\right)$ and Punishment $\left(\mathrm{X}_{2}\right)$ is $45,7 \%$, while the remaining $54,3 \%$ is the contribution / influence of other independent variables not observed in this study. The influence of these independent variables includes motivation, leadership, work environment, work culture and others.

\section{Conclusion}

From the results of research for employees of Sales Promotion Girl at Matahari Department Store Metropolitan Mall Bekasi, it can be explained that Based on the $t$ test, reward $\left(\mathrm{X}_{1}\right)$ gets the result that there is a significant positive influence between the reward program toward Job satisfaction. Based on the $t$ test, Punishment $\left(\mathrm{X}_{2}\right)$ gets the result there is a significant positive influence between punishment programs toward Job satisfaction. From the multiple linear regression test between the use of reward $\left(\mathrm{X}_{1}\right)$ and punishment $\left(\mathrm{X}_{2}\right)$ towards Job satisfaction (Y), it is obtained that there are significant positive effect simultaneously between the reward and punishment program on Job satisfaction. The results of the hypothesis testing above show that the reward and punishment program has an impact to improve job performance at Matahari Department Store Metropolitan Mall Bekasi. 


\section{References}

[1] R. Q. Danish and A. Usman, "Impact of Reward and Recognition on Job Satisfaction and Motivation: An Empirical study from Pakistan," Int. J. Bus. Manag., vol. 5, no. 2, Jan. 2010.

[2] S. Richbell and G. Wood, "Reward management," in Human Resource Management: A Critical Approach, 2009.

[3] L. W. Njanja, R. N. Maina, L. K. Kibet, and K. Njagi, "Effect of Reward on Employee Performance: A Case of Kenya Power and Lighting Company Ltd., Nakuru, Kenya," Int. J. Bus. Manag., vol. 8, no. 21, Oct. 2013.

[4] F. F. T. Chiang and T. A. Birtch, "Reward climate and its impact on service quality orientation and employee attitudes," Int. J. Hosp. Manag., vol. 30, no. 1, pp. 3-9, Mar. 2011.

[5] K. Sandhya and D. Pradeep Kumar, "Employee retention by motivation," Indian J. Sci. Technol., 2011.

[6] K. M. Carlsmith, J. M. Darley, and P. H. Robinson, "Why do we punish? deterrence and just deserts as motives for punishment," Journal of Personality and Social Psychology. 2002.

[7] D. C. Lerman and C. M. Vorndran, "On the status of knowledge for using punishment implications for treating behavior disorders.," J. Appl. Behav. Anal., 2002.

[8] R. L. Hannan, V. B. Hoffman, and D. V. Moser, "Bonus versus Penalty: Does Contract Frame Affect Employee Effort?," in Experimental Business Research, 2005.

[9] B. Sharifah, P. Joki, R. Balan, Sharifah Baharum, J. P. Sawai, and R. B. Rathakrishnan, "Hubungan Antara Komunikasi Dalam Organisasi Dengan Kepuasan Kerja, Prestasi Kerja dan Komitmen Kerja,” J. Kemanus., 2006.

[10] J. Hofmans, S. De Gieter, and R. Pepermans, "Individual differences in the relationship between satisfaction with job rewards and job satisfaction," J. Vocat. Behav., 2013. 